\title{
Correction to: New sand stabilization index of sand encroachment around green belts in Gourara, southwest of Algeria
}

\author{
Ould Safi Mohammed $^{1} \cdot$ Haddouche Driss $^{2}$
}

Published online: 6 October 2020

(C) Saudi Society for Geosciences 2020

\section{Correction to: Arabian Journal of Geosciences (2019) 12: 180.} https://doi.org/10.1007/s12517-019-4364-6

The original version of this paper was published with error. The formula of the equation Sand Stabilization Index (SSI) in the published version of the paper is missing. Given in this article is the missing formula.

S.S.I $=[(R 1 * n * \mathrm{~K})+(R 2 * n * \mathrm{~K})+(R 3 * n * \mathrm{~K})+(R 4 * n * \mathrm{~K})] / N \ldots \ldots \ldots$

S.S.I sand stabilization index.

$\mathbf{R}$ is the value of the class of sand encroachment survey $(1,2,3$ and 4) (Table 2).

$\mathbf{n}$ represents the number of survey of the same sand encroachment class (R) and the same coefficient of the sand height $(\mathrm{K})$. $\mathbf{N}$ represents the total number of the executed survey in the green band.

$\mathbf{K}$ is the coefficient of the height of the sand accumulation. It concerns the maximum height reached by the sand accumulation observed in each plot of the sand encroachment survey. We have four values of $\mathrm{K}$ (Table 2).

The online version of the original article can be found at https://doi.org/ 10.1007/s12517-019-4364-6

Ould Safi Mohammed moh.safi.forest@gmail.com

1 Laboratory N31, Conservation Management of Water, Soil and Forests Sustainable Mountain Development in the Region of Tlemcen, Department of Forest Resources, Faculty of SNV-STU, University of Tlemcen, B.P.119, 1300 Tlemcen, Algeria

2 National Institute of Forestry Research, Adrar station, Algeria 